\title{
Modulation of Gene Expression in Subjects at Risk for Colorectal Cancer by the Chemopreventive Dithiolethione Oltipraz
}

Peter J. O’Dwyer, Christine E. Szarka, Kang-Shen Yao, Theresa C. Halbherr, Gordon R. Pfeiffer, Frances Green, James M. Gallo, James Brennan, Harold Frucht, Eric B. Goosenberg, Thomas C. Hamilton, Samuel Litwin, Andrew M. Balshem, Paul F. Engstrom, and Margie L. Clapper

Fox Chase Cancer Center, Philadelphia, Pennsylvania 19111

\begin{abstract}
Prolonged exposure to mutagenic substances is strongly associated with an individual's risk of developing colorectal cancer. Clinical investigation of oltipraz as a chemopreventive agent is supported by its induction of the expression of detoxication enzymes in various tissues, and its protective activity against the formation of chemically induced colorectal tumors in animals. The goals of the present study were: to determine if oltipraz could induce detoxicating gene expression in human tissues; to identify effective nontoxic doses for more extensive clinical testing; and to establish a relationship between effects in the colon mucosa and those in a more readily available tissue, the peripheral mononuclear cell. 24 evaluable patients at high risk for colorectal cancer were treated in a dose-finding study with oltipraz $125,250,500$, or $1,000 \mathrm{mg} / \mathrm{m}^{2}$ as a single oral dose. Biochemical analysis of sequential blood samples and colon mucosal biopsies revealed increases in glutathione transferase activity at the 1ower dose levels. These effects were not observed at the higher doses. More pronounced changes were observed in detoxicating enzyme gene expression in both tissues at all doses. Peripheral mononuclear cell and colon mRNA content for $\gamma$-glutamylcysteine synthetase $(\gamma$-GCS) and DT-diaphorase increased after dosing to reach a peak on day 2-4 after treatment, and declined to baseline in the subsequent 7-10 d. The extent of induction of gene expression in colon mucosa reached a peak of 5.75-fold for $\gamma$-GCS, and a peak of 4.14-fold for DT-diaphorase at 250 $\mathrm{mg} / \mathrm{m}^{2}$; higher doses were not more effective. Levels of $\gamma$-GCS and DT-diaphorase correlated closely $(P \leq 0.001)$ between peripheral mononuclear cells and colon mucosa both at baseline and at peak. These findings demonstrate that the administration of minimally toxic agents at low doses may modulate the expression of detoxicating genes in the tissues of individuals at high risk for cancer. Furthermore, peripheral mononuclear cells may be used as a noninvasive surrogate endpoint biomarker for the transcriptional response of normal colon mucosa to drug administration. (J. Clin. Invest. 1996. 98:1210-1217.) Key words: oltipraz • gene ex-
\end{abstract}

Address correspondence to Peter J. O'Dwyer, Kimmel Cancer Center, Thomas Jefferson University, 233 S. 10th St., Suite 502, Philadelphia, PA 19107. Phone: 215-503-3155; FAX: 215-503-3074.

Received for publication 10 November 1995 and accepted in revised form 11 March 1996.

J. Clin. Invest.

(C) The American Society for Clinical Investigation, Inc. 0021-9738/96/09/1210/08 \$2.00

Volume 98, Number 5, September 1996, 1210-1217 pression - chemoprevention - DT-diaphorase $\cdot \gamma$-glutamylcysteine synthetase

\section{Introduction}

Colorectal cancer is the second leading cause of death from cancer in males and the third in females in the U.S. (1). Colon carcinogenesis has been revealed to entail a series of genetic mutations that result in the evolution of clones with progressive loss of proliferative controls, and the acquisition of the capacity to invade and metastasize (2-4). Until recently, only epidemiologic evidence identified exposure to mutagenic dietary constituents as a major factor in colorectal cancer risk (5). A molecular basis for this association has now been described in a significant subset of patients with colorectal cancer. In hereditary nonpolyposis colorectal cancer, somatic cells demonstrate inactivation of several of the genes involved in mismatch repair of DNA $(6,7)$. The loss of this DNA proofreading function is believed to facilitate the development of cancer by rendering colon epithelial cells more susceptible to mutagenesis. Analysis of DNA from the more common nonhereditary form of the disease also implicates mutagenesis in the causation of these tumors, though the basis for susceptibility has not yet been identified.

Mutagenic compounds to which colon mucosa are exposed include reactive aromatic compounds such as fecapentaenes (8), various pyrrolysis products generated during cooking (9), bile acids (10), and short-chain fatty acids (11). These toxins produce reactive molecules that may form bulky adducts to DNA, or may alter the structure of specific bases by oxidation-reduction reactions. Endogenous oxidative processes may also result in such structural lesions. The capacity to repair such DNA damage has thus been shown to underlie an individual's risk of cancer.

Protection from mutagen-induced DNA damage is achieved by a range of detoxication enzymes of broad substrate specificity. The phase II detoxication enzymes, such as glutathione (GSH) S-transferase and DT-diaphorase, play a pivotal role in protecting cells from cytotoxic damage through a variety of reactions and are currently being investigated as biomarkers of risk for various malignancies including colorectal cancer (12). The capacity to conjugate xenobiotics to GSH is determined by its intracellular availability; the synthesis of GSH is regulated by the activity of $\gamma$-glutamylcysteine synthetase $(\gamma$-GCS $),{ }^{1}$ the initial enzyme in the GSH synthetic pathway (13). A recent finding that patients with tobacco-related malignancies have lower activity of the $\mu$ isoform of GSH transferase $(14,15)$ supports a role for these systems in the protection from mu-

1. Abbreviation used in this paper: $\gamma$-GCS, $\gamma$-glutamylcysteine synthetase. 
tagens. Individuals with risk factors for colorectal cancer have significantly lower levels of GSH transferase activity in their blood lymphocytes (16). It has been hypothesized that increasing the expression of these enzymes could inhibit the initiational and/or promotional events that lead to tumor formation.

Epidemiologic studies associate a diet high in vegetable consumption with a lower risk of colorectal cancer (17-20). A mechanism by which the intake of certain vegetables (cabbage, cauliflower, broccoli, and other members of Cruciferae and Brassicae families) may protect from colon cancer is believed to be through modulation of the activity of these detoxication systems $(21,22)$. These vegetables contain many potential cancer-protective substances including in particular dithiolethiones. Oltipraz [4-methyl-5-(2-pyrazinyl)-1,2-dithiole-3-thione], (Fig. 1) is a synthetic dithiolethione that has been used in the past as an antischistosomal agent (23). In animal models, the administration of oltipraz as a dietary constituent protects rodents from the development of lung and forestomach tumors in response to alkylating agents, from hepatic tumors in response to aflatoxin $\mathrm{B}_{1}$, and from colon tumors in response to several mutagens (24-26). The mechanism of oltipraz action appears to be through elevation of the activity of various detoxicating enzymes, at least in part through transcriptional induction $(27,28)$. In the aflatoxin $\mathrm{B}_{1}$ model, oltipraz results in higher liver GSH transferase activity, which in turn increases the rate of $\mathrm{AFB}_{1}$ metabolism, and decreases the formation of $\mathrm{AFB}_{1}$-DNA adducts $(27,29)$. Administration of oltipraz to mice also protects against the acute hepatotoxicity associated with acetaminophen and carbon tetrachloride exposure (30).

Previous experience with oltipraz as an antischistosomal drug had identified a dose range and some side effects that might be expected in a clinical trial (31). Benson and colleagues identified dermatologic and neurologic toxicity in a trial of daily oral oltipraz for up to 6 mo (32). Since a successful chemopreventive drug will be administered long-term to asymptomatic and essentially healthy people, the drug should be minimally toxic at biologically effective doses.

To determine if modulation of gene expression may be a viable approach to cancer prevention, we performed a clinical study of oltipraz with biochemical and biological endpoints. We focused upon a small number of detoxication mechanisms: the GSH transferases, the two electron bioreductive enzyme DT-diaphorase, and GSH itself, together with the expression of $\gamma$-GCS. We found that at nontoxic doses, oltipraz administration resulted in the induction of the expression of genes encoding several detoxication enzymes. These observations demonstrate that the capacity of colon epithelial cells to resist mutagenic damage can be upregulated, and support the hypothesis that induction of the gene expression of protective enzymes may be feasible as an approach to cancer prevention.

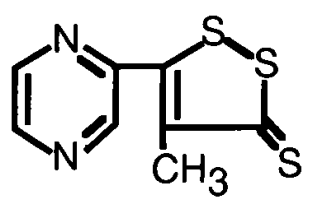

\section{OLTIPRAZ Figure 1. Structure of oltipraz.}

\section{Methods}

\section{Study population}

Eligible patients were at increased risk for colorectal carcinoma and included men and women over the age of 18 with a family history of colorectal cancer, a personal history of colon polyps or a personal history of colorectal cancer ( $>3$ mo from definitive treatment). Individuals were deemed ineligible if they had: $(a)$ a known untreated primary or metastatic carcinoma; $(b)$ hereditary nonpolyposis colorectal carcinoma; (c) familial adenomatous polyposis syndrome; $(d)$ a history of colitis (inflammatory, radiation induced, or Crohn's disease), or (e) significant medical or psychiatric problems which would make them poor protocol candidates. A medical history, physical examination, complete blood count, prothrombin time, partial thromboplastin time, fibrinogen, biochemical profile, urinalysis, and electrocardiogram were performed for all individuals.

All eligible participants were physiologically normal, as evidenced by an Eastern Cooper Oncology Group (ECOG) performance status of 0 and adequate bone marrow (white blood cell count $\geq$ $4,000 / \mathrm{mm}^{3}$, platelet count $\geq 100,000 / \mathrm{mm}^{3}$, hemoglobin $\geq 11 \mathrm{grams} / \mathrm{dl}$ ), renal (serum creatinine $\leq 1.5 \mathrm{mg} / \mathrm{dl}$ ), and liver (total bilirubin $\leq 1.5$ $\mathrm{mg} / \mathrm{dl}$ ) function. All subjects were asked to refrain from the use of aspirin, nonsteroidal antiinflammatory drugs, and corticosteroids during the study time period. All patients gave written informed consent in accordance with Federal, State and institutional guidelines.

\section{Treatment plan}

During enrollment 26 individuals completed a general health history questionnaire regarding personal and family health history. Twenty eligible high-risk individuals enrolled and were randomized to one of three single dosages of oltipraz $\left(250,500\right.$, or $\left.1,000 \mathrm{mg} / \mathrm{m}^{2}\right)$. Based on the biochemical and biological analyses conducted upon tissues derived from the initial group, an additional cohort of six patients was entered at $125 \mathrm{mg} / \mathrm{m}^{2}$.

After an overnight fast, the assigned dose of oltipraz (rounded to the nearest $20 \mathrm{mg}$ ) was administered orally with eight ounces of water under supervision in the Mary S. Schinagl Clinical Pharmacology Unit at Fox Chase Cancer Center (Philadelphia, PA). Oltipraz was synthesized by Rhone-Poulenc Rorer (Vitry-sur-Seine, France) and supplied for this trial by the Division of Cancer Prevention and Control (Bethesda, MD) in capsules that ranged in size from 20 to $250 \mathrm{mg}$. Subjects were permitted to begin eating and drinking $5 \mathrm{~h}$ after dosing.

Patients were monitored with weekly interviews to record side effects, blood counts, coagulation indices, and biochemical profiles for 4 wk after dosing. Results are reported using the National Cancer Institute Common Toxicity Criteria (1988. NCI, Bethesda, MD).

\section{Preparation of tissues}

Peripheral mononuclear cells. Pretreatment and 1, 2, 3, 8, and $14 \mathrm{~d}$ after dosing, blood samples were drawn into heparinized tubes by venipuncture for biochemical and molecular analyses. They were immediately transported to the laboratory at room temperature, layered over lymphocyte separation medium (Organon-Teknika, Durham, NC), and centrifuged. The mononuclear cell layer was pipetted into a $1-\mathrm{ml}$ vol, washed twice with PBS, and stored as a dry pellet at $-70^{\circ} \mathrm{C}$. At the time of analysis, samples were thawed on ice. The blood lymphocytes were lysed by pulsed sonication for $30 \mathrm{~s}$ (550 sonic dismembrator; Fisher Scientific Co. Pittsburgh, PA) and centrifuged at 10,000 $g$ for $3 \mathrm{~min}$ at $4^{\circ} \mathrm{C}$.

An additional blood sample $(10 \mathrm{ml})$ was obtained before dosing and stored at $4^{\circ} \mathrm{C}$ for GSH transferase $\mu$ genotyping. Lymphocytes were separated from whole blood within $24 \mathrm{~h}$ as described above. Isolated lymphocytes were washed with phosphate buffered saline $(\mathrm{pH}$ 7.0), resuspended in $\mathrm{NH}_{4} \mathrm{Cl}$ buffer to lyse red cells, washed, pelleted, and frozen at $-80^{\circ} \mathrm{C}$.

Colon mucosa. Biopsies of the colon mucosa were obtained by flexible sigmoidoscopy before and 3 and 8 days after treatment, following limited bowel preparation in the Minor Procedure Room of 
the Outpatient Department at the Fox Chase Cancer Center. After a detailed explanation of the procedure, the patient was placed in a left lateral decubitus position and the sigmoidoscope inserted. Multiple tissue biopsies ( $n=5$; $~ 3-20 \mathrm{mg}$ each) were obtained from the sigmoid colon $(\sim 20 \mathrm{~cm}$ from the anal verge), immediately frozen in liquid nitrogen and stored at $-80^{\circ} \mathrm{C}$. At the time of analysis, one biopsy sample of the colon mucosa was thawed on ice, immersed in a $1 \mathrm{ml}$ of $10 \mathrm{mM}$ Tris $\mathrm{HCl}$ ( $\mathrm{pH}$ 7.8), and homogenized (Omni 1000 homogenizer; Omni International, Waterbury, CT). Supernatant for analysis was obtained by centrifugation at $10,000 \mathrm{rpm}$ for 15 minutes at $4^{\circ} \mathrm{C}$.

\section{Tissue analysis}

Glutathione levels and glutathione transferase activity. GSH transferase activity was assayed spectrophotometrically by the method of Habig et al. (33), which measures the rate of formation of a conjugate of 1-chloro-2,4-dinitrobenzene (CDNB) (Sigma Chemical Co., St. Louis, MO) and glutathione. GSH levels were measured by the method of Griffith et al (34). Results were normalized to protein content using the Bradford assay (Bio-Rad Laboratories, Richmond, CA).

DT-diaphorase activity. The cytosolic activity of DT diaphorase in colon tissue was assessed in the presence of the electron acceptor 2,6-dichlorophenolindophenol (DCPIP) (Sigma Chemical Co.) and bovine serum albumin (35). The spectrophotometric assay monitored the oxidation of NADPH, and specific activity was expressed as $\mathrm{nmol} / \mathrm{min}$ per $\mathrm{mg}$ protein. Activity was reassessed after the addition of dicoumarol (Sigma Chemical Co.) to quantitate the level of enzymatic activity specific to DT-diaphorase.

Glutathione S-transferase $\mu$ genotyping. The GSH transferase $\mu$ genotype was determined in DNA that was extracted from pelleted lymphocytes by the salting-out method (36). PCR was performed with primers to exon 4 (5'-CTGCCCTACTTGATTGATGGG-3') and exon 5 (5'-CTGGATTGTACGAGATCATGC-3') of GSH transferase $\mu$ and primers (5'-ACACAACTGTGTTCACTAGC-3' and $5^{\prime}$-CAACTTCATCCACGTTCACC- $3^{\prime}$ ) to the $\beta$ globin gene as internal positive controls (37). PCR reactions were carried out in a $50-\mu$ l solution containing: primers $(4 \times 500 \mathrm{nM}), T a q$ polymerase $(1 \mathrm{U})$, DNTP $(4 \times 0.2 \mathrm{nM})$, target DNA $(0.5 \mu \mathrm{g})$, and buffer (Tris/ $\left.\mathrm{HCl} 10 \mathrm{mM}, \mathrm{MgCl}_{2} 1.5 \mathrm{mM}, \mathrm{KCl} 50 \mathrm{mM}\right)$. DNA was initially denatured at $94^{\circ} \mathrm{C}$ for $1 \mathrm{~min}$ and cycled as described previously (37). PCR

\section{Table I. Demographics}

\begin{tabular}{|c|c|c|}
\hline Evaluable participants $(n)$ & 24 & \\
\hline \multicolumn{3}{|l|}{ Age (yr) } \\
\hline Median & 61 & \\
\hline Range & $40-80$ & \\
\hline Sex & & $(\%)$ \\
\hline Male & 16 & $(67)$ \\
\hline Female & 8 & (33) \\
\hline Risk Factors & & $(\%)$ \\
\hline History of colorectal cancer & 2 & (8) \\
\hline History of colorectal polyps & 1 & (4) \\
\hline Family history of colorectal cancer & 12 & $(50)$ \\
\hline $\begin{array}{l}\text { History of colorectal cancer and } \\
\text { colorectal polyps }\end{array}$ & 1 & (4) \\
\hline $\begin{array}{l}\text { History of colorectal polyps and family } \\
\text { history of colorectal cancer }\end{array}$ & 7 & (29) \\
\hline $\begin{array}{l}\text { History of colorectal cancer, polyps, and } \\
\text { family history of colorectal cancer }\end{array}$ & 1 & (4) \\
\hline Tobacco usage & & $(\%)$ \\
\hline Nonsmoker & 8 & (35) \\
\hline Current smoker & 4 & (17) \\
\hline Quit $\leq 5 \mathrm{yr}$ & 3 & (13) \\
\hline Quit $\geq 5 \mathrm{yr}$ & 8 & (35) \\
\hline
\end{tabular}

products were electrophoresed in $2 \% \mathrm{wt} / \mathrm{vol}$ agarose gels, stained with ethidium bromide, and photographed under ultraviolet light.

$\gamma-G C S$ and DT-diaphorase expression by PCR-RNA assay. Total RNA was isolated from colon mucosa and peripheral mononuclear cells using standard methods (38). $\gamma$-GCS and DT-diaphorase expression was quantitated using the PCR-reverse transcriptase assay. The principal technique used was that described by Horikoshi and coworkers (39). Total RNA (100 ng) for each reaction was used and varying amounts of cDNA from the reverse transcriptase reactions were used as substrate for PCR amplification of $\gamma$-GCS, DT-diaphorase, and $\beta$-actin. The PCR reaction mixtures $(25 \mu \mathrm{l}$ total volume, containing 1-10 $\mathrm{nl}$ of cDNA, $12.5 \mathrm{pmol}$ of each of the appropriate primer pairs, $100 \mathrm{mM}$ Tris, $\mathrm{pH} 8.3,500 \mathrm{mM} \mathrm{KCl}_{2}, 0.01 \%$ gelatin, $0.5 \mu \mathrm{l}$ of 10 $\mathrm{mM}$ aqueous deoxynucleotide triphosphate solution, and $3.75 \mu \mathrm{l}$ of $12.5 \mathrm{mM} \mathrm{Mg} \mathrm{Cl} 2$ ) were amplified for 35 cycles at $94^{\circ} \mathrm{C}$ for $1 \mathrm{~min}$, at $52^{\circ} \mathrm{C}(\gamma$-GCS $)$ or $55^{\circ} \mathrm{C}\left(\beta\right.$-actin) for $1 \mathrm{~min}$, and $72^{\circ} \mathrm{C}$ for $1 \mathrm{~min}$. The $\gamma$-GCS PCR primers with $\mathrm{T}_{7}$ polymerase promoter sequence TAATACGACTCACTATA attached to their $5^{\prime}$ ends were GCS-28

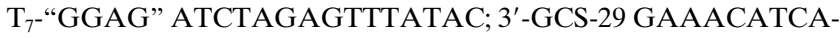
TAGATA based on the $\gamma$-GCS gene coding region sequence (40). The DT-diaphorase PCR $5^{\prime}$ primer with $\mathrm{T}_{7}$ polymerase promoter sequence was 1 TAA TACGACTCACTA TAG GAG AGG CTG

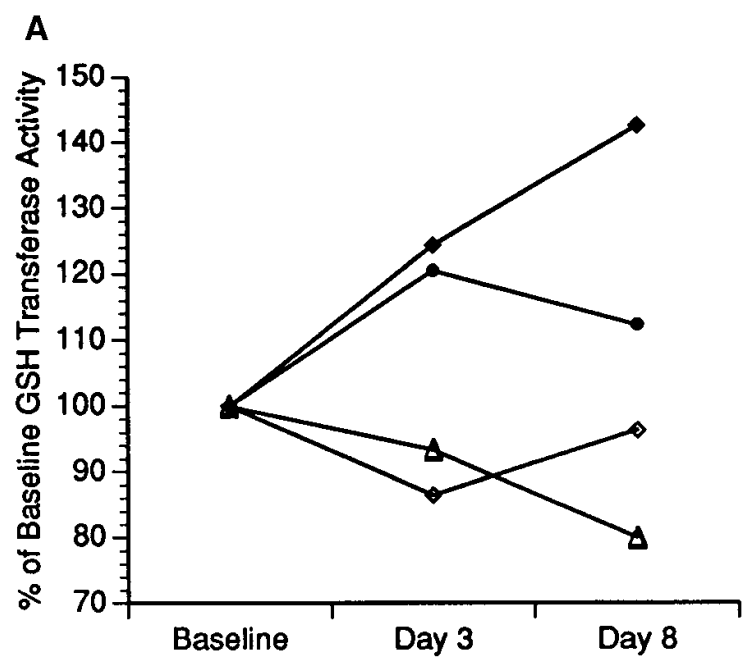

B

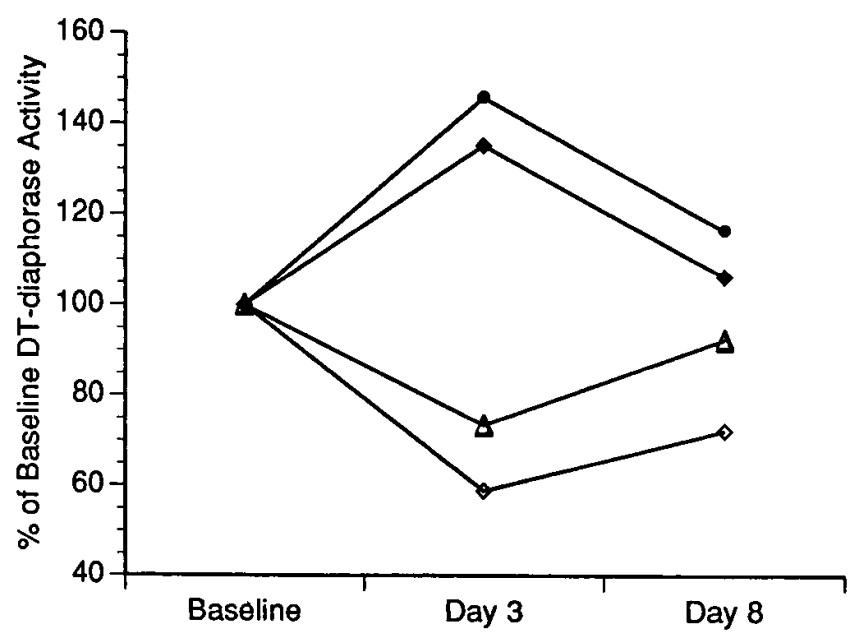

Figure 2. Catalytic activity of GSH transferase $(A)$ and DT-diaphorase $(B)$ expressed as percentage change from baseline in colon mucosa after treatment with oltipraz at the indicated doses. $(\diamond) 125 \mathrm{mg} /$ $\mathrm{m}^{2} ;(\bullet) 250 \mathrm{mg} / \mathrm{m}^{2} ;(\diamond) 500 \mathrm{mg} / \mathrm{m}^{2} ;(\triangle) 1,000 \mathrm{mg} / \mathrm{m}^{2}$. 
GTT TGA GCG AGT GTTC; the $3^{\prime}$ primer was ATT TGA ATTCGG GCG TCT GCTG (41). The $\beta$-actin gene primer: BA-67 $\mathrm{T}_{7^{-}}$"GGGAGA" GCGGGAAATCGTCGTGCGTGACATT (bases 2104-2127 of the $\beta$-actin genomic sequence, located in exon 3) (42) and BA-68 GATGGAGTTGAAGGTAGTTTCGTG (bases 24092432 of the $\beta$-actin genomic sequence, located in exon 4) (42) were used for an internal control. For $\mathrm{T}_{7}$ polymerase transcription, $3 \mu \mathrm{l}$ of PCR product was used with $22 \mu \mathrm{l}$ of a master solution containing transcription buffer ( $40 \mathrm{mM}$ Tris- $\mathrm{HCl}, \mathrm{pH} 7.5,12 \mathrm{mM} \mathrm{MgCl}_{2}, 1 \mathrm{mM}$ spermidine); $1 \mathrm{mM}$ each of the ribonucleotides (ATP, GTP, CTP, and UTP), $0.1 \mathrm{M}$ dithiothreitol, $10 \mu \mathrm{l}$ of RNA guard, $2.5 \mu \mathrm{Ci}$ of $\left[\alpha{ }^{-32} \mathrm{P}\right]$ CTP $(3,000 \mathrm{Ci} / \mathrm{mmol})$, and $50 \mathrm{U}$ of $\mathrm{T}_{7} \mathrm{RNA}$ polymerase solution. The mixture was incubated for $1 \mathrm{~h}$ at $37^{\circ} \mathrm{C}$. After stopping the reaction with $0.75 \mu \mathrm{l}$ of $0.5 \mathrm{M}$ EDTA, the transcription mixture was electrophoresed on an $8 \%$ urea-denatured polyacrylamide gel at $200 \mathrm{~V}$ for $3 \mathrm{~h}$. After drying the gel under vacuum, autoradiography was performed overnight. The bands for $\gamma$-GCS, DT-diaphorase, and $\beta$-actin gene fragments were cut out and counted in a liquid scintillation counter. To normalize the $\gamma$-GCS and DT-diaphorase expression to that of the endogenous standard $\beta$-actin, the ratio between the amount of the radiolabeled PCR product within the linear amplification range and the endogenous standard was calculated as the ratio of PCR products.

\section{Statistical methods}

Differences between baseline and post treatment values of the several measurements were tested for statistical significance using the Wilcoxon or Kruskal-Wallis nonparametric tests, $t$ tests, or ANOVA. In some cases the parametric test was significant when the nonparametric one gave a $P$ value slightly over $5 \%$. Both test results are reported in such cases. Comparisons across doses were tested using the corresponding two sample versions of the Wilcoxon and $t$ tests. Spearman's nonparametric test was used to evaluate correlations between colonic tissue measurements and those in peripheral mononuclear cells. All tests were carried out using SAS ${ }^{\circledR}$ software, in particular, using proc univariate, proc npar1way, and proc GLM.

\section{Results}

26 eligible individuals enrolled in this study. Two individuals withdrew before receiving drug and thus were not evaluable. One individual was unable to provide the blood samples required for analyses secondary to poor venous access while the second withdrew due to a poor experience with his first endoscopic procedure. All participants were caucasian with an ECOG performance status of 0 . The majority of individuals were recruited from outside the Fox Chase Cancer Center and thus did not have a personal history of colorectal cancer. $83 \%$ of enrollees were at higher risk for colorectal cancer by virtue of the occurrence of the disease in a first-degree relative (Table I).

After the single dose of oltipraz, side-effects were minimal and of questionable relationship to drug administration. Two subjects experienced grade 1 nausea (one at 500, one at 1,000 $\mathrm{mg} / \mathrm{m}^{2}$ ), and a subject at $500 \mathrm{mg} / \mathrm{m}^{2}$ had grade 1 diarrhea. No subjects at the 125 or $250 \mathrm{mg} / \mathrm{m}^{2}$ dose levels had any adverse symptoms. Thus a single dose of oltipraz at these levels was well tolerated.

23 subjects were tested for the genotype of the GSH transferase $\mu$ subclass which is present in $40-60 \%$ of the general population (43-45). DNA analysis revealed only 6/23 (26\%) positive, while the remainder $(17 / 23,74 \%)$ were null for this locus.

Biochemical effects in peripheral mononuclear cells and colon. The peripheral mononuclear cell GSH transferase activity (mean $\pm \mathrm{SEM}$ ) was $62.3 \pm 3.8 \mathrm{nmol} / \mathrm{min}$ per $\mathrm{mg}$. In colon $\mathrm{mu}-$ cosa the baseline activity was $79.5 \pm 4.4 \mathrm{nmol} / \mathrm{min}$ per $\mathrm{mg}$.; both findings are consistent with previous observations (16). Subjects with positive GSH transferase $\mu$ expression (by genotype) had higher GSH transferase catalytic activity in peripheral mononuclear cells $(74.9 \pm 7.6 \mathrm{nmol} / \mathrm{min}$ per $\mathrm{mg})$ than those with the null genotype $(58.4 \pm 4.2)(P=0.0209$, Kruskal-Wallis test). A similar though nonsignificant trend (76.3 vs 91.0$)$ was evident in colon mucosa.

The lower doses of oltipraz significantly modulated the GSH transferase activity in colon tissue (Fig. $2 A$ ). Oltipraz $\left(125 \mathrm{mg} / \mathrm{m}^{2}\right)$ increased mean baseline GSH transferase activity from $75.3 \pm 7 \mathrm{nmol} / \mathrm{min}$ per $\mathrm{mg}$ to $91.8 \pm 5.9 \mathrm{nmol} / \mathrm{min}$ per $\mathrm{mg}$ on day $3(P=0.062$ Wilcoxon signed rank test; $P=0.01, t$ test $)$ and to $102.2 \pm 5.3 \mathrm{nmol} / \mathrm{min}$ per $\mathrm{mg}$ on day $8(P=0.156$, Wilcoxon; $P=0.042, t$ test $)$. Oltipraz $\left(250 \mathrm{mg} / \mathrm{m}^{2}\right)$ increased mean baseline GSH transferase activity of $71.7 \pm 10 \mathrm{nmol} / \mathrm{min}$ per $\mathrm{mg}$ to $87.0 \pm 14 \mathrm{nmol} / \mathrm{min}$ per $\mathrm{mg}$ on day 3 only $(P=0.062$, Wilcoxon; $P=0.036, t$ test). In peripheral mononuclear cells, only the $125 \mathrm{mg} / \mathrm{m}^{2}$ dose of oltipraz had a significant effect. The mean baseline GSH transferase activity increased from $72.6 \pm 9 \mathrm{nmol} /$ min per $\mathrm{mg}$ to $82.4 \pm 11 \mathrm{nmol} / \mathrm{min}$ per $\mathrm{mg}$ on day 3 only $(P=$ 0.0031 , Wilcoxon). Similar though nonsignificant changes were observed in DT-diaphorase activity in colon mucosa (Fig. $2 B$ ). None of the doses of oltipraz studied had a clinical effect on the GSH content of either colon or peripheral mononuclear cells.

Alteration in gene expression in peripheral mononuclear cells and colon. Quantitation of gene expression by the reverse transcriptase-polymerase chain reaction method is described relative to the expression of a control gene, commonly $\beta$-actin. The mean pretreatment DT-diaphorase expression in PMNs was $4.4 \pm 0.7$, and ranged from 0.4 to 13.5 (relative units), an observation that reflects substantial interpatient variability. The mean expression in colon mucosa was $3.5 \pm 0.4$ (range 0.8-9.4). The mean pretreatment values for $\gamma$-glutamylcysteine synthase expression in PMNs was $1.2 \pm 0.1$ (range $0.2-$ 2.8 ), and in colon mucosa $1.3 \pm 0.1$ (range $0.5-3.4$ ). This degree

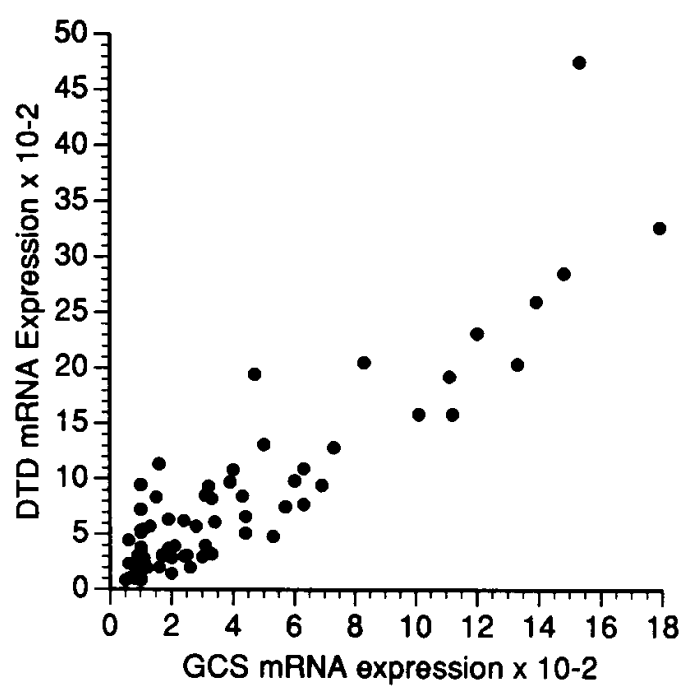

Figure 3. Plot of the mRNA expression (relative to that of $\beta$-actin, expressed in arbitrary units) of DT-diaphorase (DTD) versus $\gamma$-GCS in the colon mucosa of individual patients. This plot shows all measurements; therefore an individual may be represented as many as three points. 
A

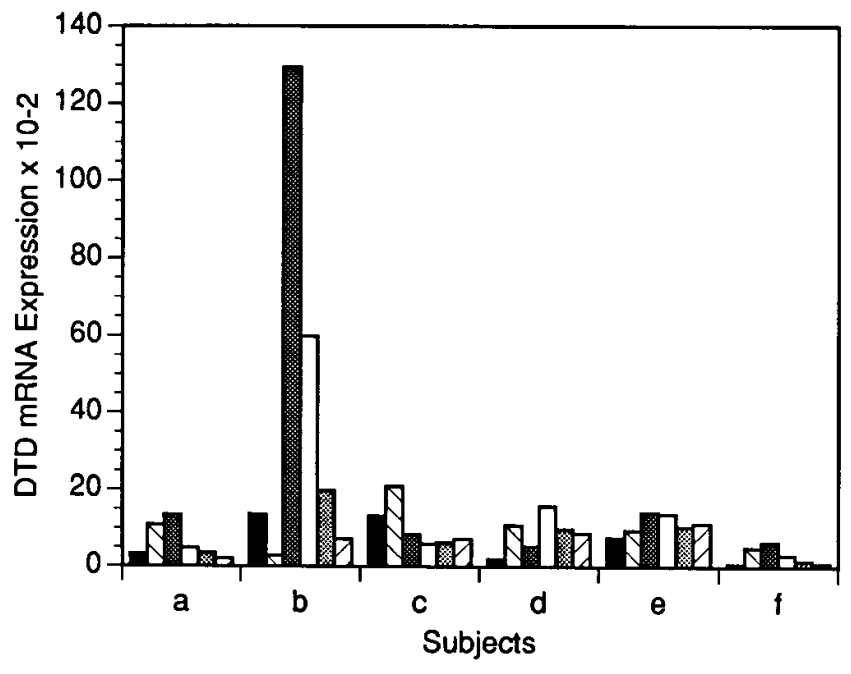

Peripheral Mononuclear Cells

B

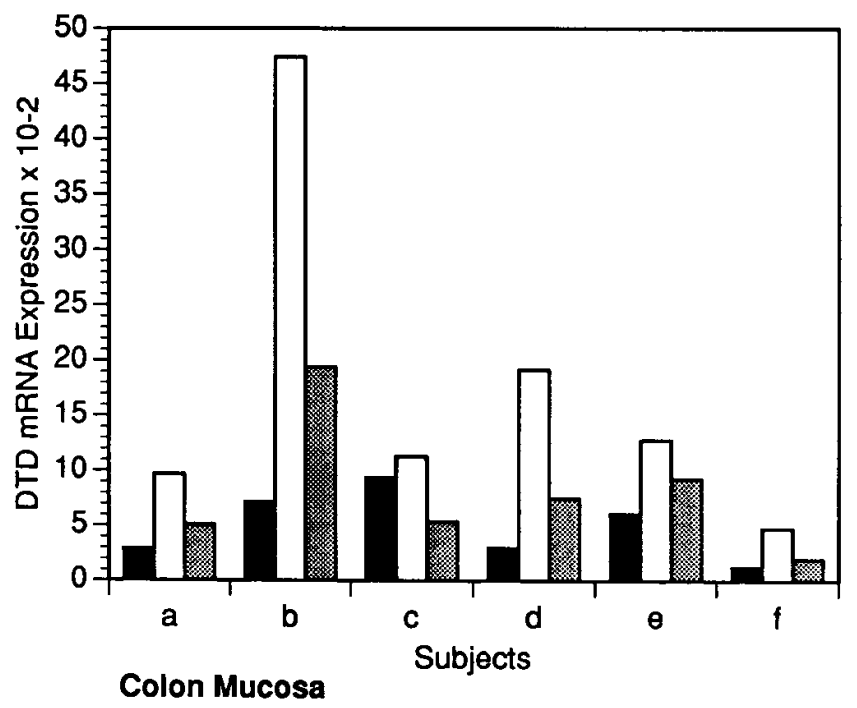

Figure 4. DT-diaphorase $(D T D)$ and $\gamma$-GCS mRNA content in $(A)$

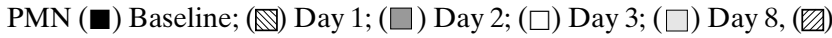
Day 14 and $(B)$ colon mucosa in patients sampled before and at intervals after a single dose of oltipraz $\left(250 \mathrm{mg} / \mathrm{m}^{2}\right)$ (ם) Baseline; $(\square)$ Day 3; $\square$ ) Day 8 .

of variability in $\gamma$-GCS expression has been observed in previous studies in cancer patients (46).

A plot of DT-diaphorase versus $\gamma$-GCS expression from in colon mucosa using all available values from every subject is shown (Fig. 3). These data demonstrate a direct association between the expression of these detoxication genes $(r=0.8983$, Pearson correlation coefficient). A similar relationship obtains for peripheral mononuclear cells $(r=0.8186$, Pearson correlation coefficient).

Treatment with a single dose of oltipraz resulted in a substantial increase in the expression of both genes in each tissue at all dose levels examined. The expression (relative to $\beta$-actin) of DT-diaphorase and of $\gamma$-GCS in peripheral mononuclear
A

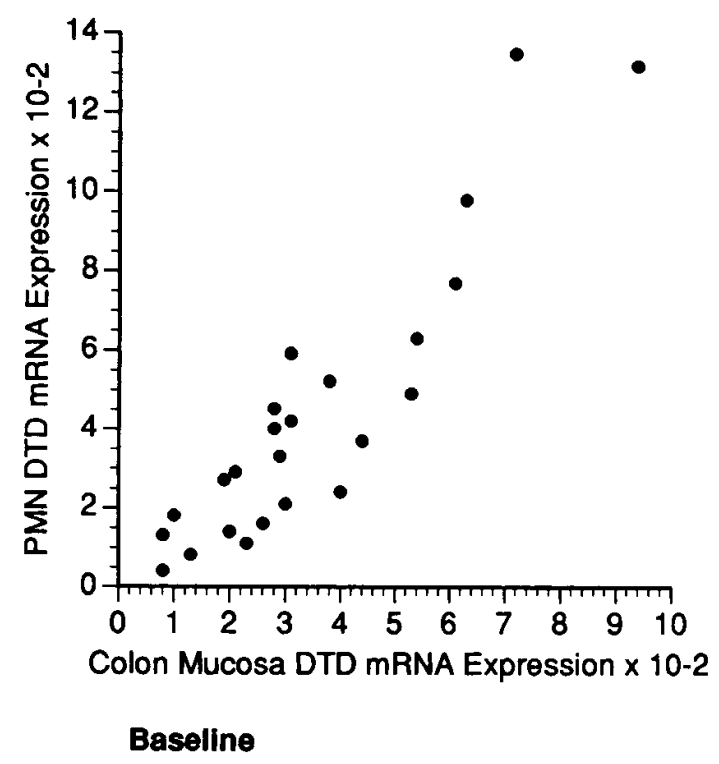

B

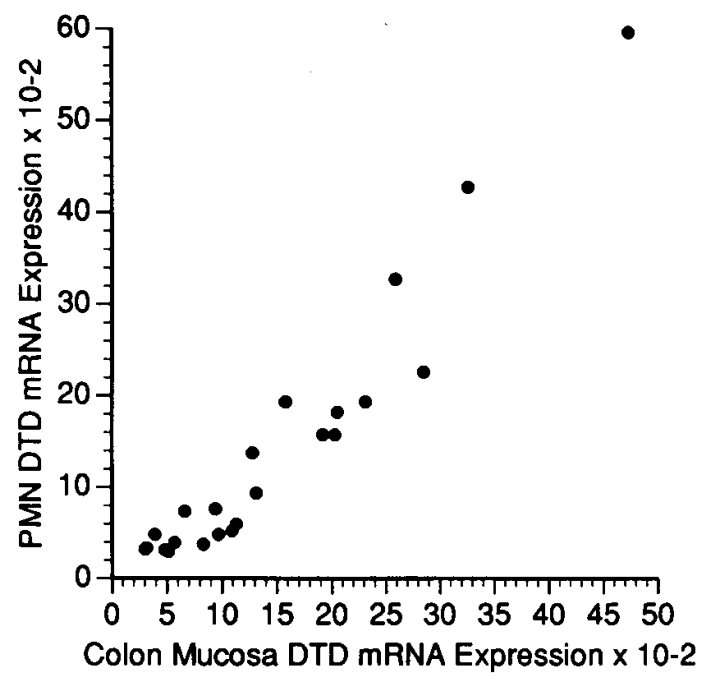

Day 3

Figure 5. Relationship between the expression of DT-diaphorase $(D T D)$ in PMN and colon mucosa $(A)$ before and $(B)$ on day 3 after treatment with oltipraz (250 to $1,000 \mathrm{mg} / \mathrm{m}^{2}$ ).

cells (Fig. $4 \mathrm{~A}$ ) and colon mucosa (Fig. $4 \mathrm{~B}$ ) is shown for the $250 \mathrm{mg} / \mathrm{m}^{2}$ dose level. Although interindividual variability in the response of peripheral mononuclear cell $\gamma$-GCS and DTdiaphorase to oltipraz was observed, subjects usually displayed peak levels at $3 \mathrm{~d}$ after treatment. Results obtained at 500 and $1,000 \mathrm{mg} / \mathrm{m}^{2}$ were almost identical. At $125 \mathrm{mg} / \mathrm{m}^{2}$, responses were diminished, but the time-course of response was preserved. The quantitative changes in gene expression in the colon mucosa are shown (Table II). At all doses tested values for DT-diaphorase and $\gamma$-GCS expression were significantly higher over time than at baseline $(P<0.0001)$. The day 8 values were still significantly different from baseline $(P<0.001)$ but it is clear that the pharmacologic effects are reversing by this time 
Table II. DT-diaphorase and $\gamma$-GCS expression in colon mucosa (Values represent mean of expression relative to $\beta$-actin, \pm SEM

\begin{tabular}{ccccc}
\hline \multicolumn{5}{c}{ Colon } \\
Dose & 125 & 250 & 500 & 1000 \\
$n$ & 6 & 6 & 6 & 6 \\
Day 0 & $2.00 \pm 0.5$ & $4.98 \pm 1.3$ & $2.95 \pm 0.4$ & $4.13 \pm 0.7$ \\
Day 3 & $5.80 \pm 1.56$ & $17.53 \pm 6.23$ & $16.28 \pm 4.4$ & $18.62 \pm 3.1$ \\
Day 8 & $2.60 \pm 0.82$ & $8.12 \pm 2.47$ & $6.67 \pm 2.35$ & $6.62 \pm 1.15$ \\
\multicolumn{5}{c}{ Colon mucosa: $\gamma$-GCS mRNA } \\
Day 0 & $1.38 \pm 0.4$ & $1.48 \pm 0.4$ & $0.93 \pm 0.2$ & $1.33 \pm 0.2$ \\
Day 3 & $3.47 \pm 0.52$ & $7.42 \pm 2.05$ & $8.78 \pm 2.76$ & $9.83 \pm 1.70$ \\
Day 8 & $2.10 \pm 0.41$ & $2.78 \pm 0.85$ & $3.92 \pm 1.46$ & $3.22 \pm 0.75$ \\
& \multicolumn{5}{c}{}
\end{tabular}

(Table II). No further increase in response was observed beyond doses of $250 \mathrm{mg} / \mathrm{m}^{2}$.

Since sampling of colon mucosa is invasive and impractical in large scale trials, we asked if gene expression in the colon was correlated with that in peripheral mononuclear cells within an individual. Fig. 5 shows that the quantitative expression of DT-diaphorase mRNA in each tissue was closely correlated at baseline and on day 3 after treatment $(P<0.0001)$. Similar findings were observed for $\gamma$-GCS. The expression of DTdiaphorase in peripheral mononuclear cells is 1.2-fold that in colon mucosa, while for $\gamma$-glutamylcysteiene synthetase, the ratio is 0.95 . These findings demonstrate clearly that the peripheral mononuclear cell can be used as a surrogate tissue to monitor changes in detoxicating gene expression in colon mucosa.

\section{Discussion}

Exogenous and endogenous mutagens are considered to initiate neoplastic transformation in colon epithelial cells, and to contribute to its malignant progression in the development of colon cancer (2). Physiologic systems that protect cells from the action of the mutagens include some oxidoreductases (such as DTdiaphorase), conjugating enzymes (such as GSH transferases), and the availability of GSH itself. Additional protection may be afforded by the capacity of the cell to repair the mutagenic lesions. Preclinical studies show that oltipraz and other dithiolethiones induce the activity of many of these protective systems.

A model for colon neoplasia is provided by rodents, which when administered large doses of carcinogens, develop colon adenomas and adenocarcinomas, the progression of which appears to recapitulate that of human disease. The co-administration of oltipraz protects animals from the development of tumors (24-27). In an aflatoxin-induced hepatoma model, oltipraz administration was associated with the formation of fewer aflatoxin-DNA adducts, and enhanced inactivation of the carcinogen by metabolism. The efficacy of oltipraz was found to correlate with induction of GSH transferases (27), and this effect was further attributed to transcriptional induction mediated through the antioxidant response element, a promoter sequence common to many of the genes encoding detoxicating enzymes (28). Thus the demonstration of the induction of gene expression in humans treated with oltipraz is an essential step in its clinical development.

In this study we have shown that oltipraz administration induces the expression of several detoxicating genes associated with protection from cancer. In colon mucosa, a significant increase in the activity of GSH transferase was observed at nontoxic doses. Effects at the mRNA level are substantially greater than those measured by biochemical assays. At $250 \mathrm{mg} / \mathrm{m}^{2}$, a mean increase in the steady state mRNA levels of 4.14-fold for DT-diaphorase and 5.75-fold for $\gamma$-glutamylcysteine synthetase was observed in both colon mucosa and peripheral mononuclear cells. These increases are substantial and are equivalent to those associated with protection in preclinical models $(26,28)$. Further, the observed changes follow a timecourse consistent with observations in mice, in which peak values were also observed $3 \mathrm{~d}$ after dosing (47). A similar lag in maximal effects is observed in vitro (48). These results establish that the pharmacologic effects of oltipraz in humans would be expected to afford protection from mutagenic insults. Though we have measured pharmacodynamic effects only in the colon and peripheral mononuclear cells, it may be anticipated from murine studies that equivalent changes will be observed in other tissues, including liver, lung, and bladder (47). Thus, based upon these data, studies of oltipraz are to be conducted in patients at high risk for lung, breast, and prostate cancers in addition to colon cancer.

A clear difference is observed between the degree of induction of gene transcription and the increase in detoxicating enzyme activity. While at the $250 \mathrm{mg} / \mathrm{m}^{2}$ dose level the mRNA content for DT-diaphorase and $\gamma$-GCS is elevated by 4.14- to 5.75-fold in colon mucosa, the activity of DT-diaphorase and of GSH transferase undergoes relatively modest elevation (Fig. 2, $A$ and $B$ ). Despite similar induction of mRNA in PMNs, the activity of the enzymes does not change reproducibly. Indeed, DT-diaphorase activity is essentially unmeasurable in peripheral mononuclear cells under normal circumstances. It is possible that translational regulatory influences result in damping of the inductive response; other possibilities include altered posttranslational processing and altered protein stability. It is possible that these mechanisms will be overcome by repetitive dosing with oltipraz, which provides optimal protection in the murine studies (24). A trial to test repeated doses of oltipraz in humans is currently in progress.

The biochemical result of a greater elevation in GSH transferase activity in colon mucosa at the lower than at the higher doses was unexpected. In contrast, dose-dependent increases in GSH transferase expression have been observed in mice (49). Though studies in vivo noted an apparent threshold effect in oltipraz' protective action (25). The apparent paradox may reflect uncertainties concerning the molecular mechanism of oltipraz. It has been shown that oltipraz results in transcriptional induction of the GSH transferase Ya isoenzyme through an interaction with the antioxidant response element in its promoter. However, the signal transduction of that response is unknown. We have previously shown that oltipraz induces nuclear factor binding to the NF- $\mathrm{B}$ element in the DT-diaphorase promoter (48). This element is thought to respond to oxidative not reductive stress, but the basis for such an action by oltipraz remains to be elucidated. These observations do allow the possibility however that the therapeutic effects of oltipraz at low doses may be opposed by toxic effects through alternative mechanisms at higher doses. Since either reductive (50) or oxidative (Yao et al., manuscript submitted for publication) stress may both result in the induction of DT-diaphorase gene expression, this hypothesis is also consistent with the observed mRNA effects. 
Although the numbers are small, our results would support the contention that the GSH transferase $\mu$ null genotype is a risk factor for colorectal cancer. This finding is in contrast to that of Peters and coworkers (51) who report that the frequency of GSH transferase $\mu$ expression in individuals with polyposis coli or colon cancer is similar to that of controls. A combined analysis of subjects with adenocarcinoma of the stomach and colon demonstrated a significant increase in the incidence of the GSH transferase $\mu$ deletion in this cancer group (52).

Indices of gene expression are a potentially powerful tool in the investigation of drug action. The wide interindividual variation in baseline expression of detoxicating genes is likely to account for much variability in pharmacologic effects. The close relationship between the expression of two unrelated detoxicating genes (Fig. 3) suggests that additional determinants of gene expression will be found to vary among individuals. The data suggest that DT-diaphorase and $\gamma$-GCS may be coregulated. It will be of value to determine if this may occur at the level of promoter activity or distally, since the underlying common mechanism may contribute directly to the individual's risk of cancer at a particular level of mutagen exposure.

Aspects of these interactions can be studied in large populations without the discomfort and expense of repeated sigmoidoscopy. The close correlation between peripheral mononuclear cells and colon epithelial cells in the baseline and in peak expression of these detoxicating genes establishes the role of the peripheral mononuclear cell as a surrogate tissue when gene expression is the endpoint. The availability and ease of sampling of peripheral mononuclear cells will allow the inclusion of pharmacodynamic investigations in future populationbased studies.

In conclusion, this study presents one of the first demonstrations of the modulation of gene expression in humans by a potential chemoprevention agent. The results define the doses of interest for the long-term administration of oltipraz, and facilitate such studies by defining an appropriate surrogate tissue for events in the colon mucosa.

\section{Acknowledgments}

The authors gratefully acknowledge the expert secretarial assistance of Catherine Thompson.

This work was supported in part by grants CN 15345 and CA 06927 from the National Cancer Institute, DHHS, a grant from the Hamilton family foundation, and a subvention from the Commonwealth of Pennsylvania.

\section{References}

1. Boring, C.C., T.S. Squires, T. Tong, and S. Montgomery. 1994. Cancer statistics. CA Cancer J. Clin. 44:18-19.

2. Vogelstein, B., E.R. Fearon, S.R. Hamilton, S.E. Kern, A.C. Preisinger, M. Leppert, Y. Nakamura, R. White, A.M. Smits, and J.L. Bos. 1987. Genetic alterations during colorectal-tumor development. N. Engl. J. Med. 319:525-32.

3. Lothe, R.A., P. Peltomaki, G.I. Meling, L.A. Aaltonen, M. NystromLahti, L. Pylkkanner, K. Heindal, T.I. Andersen, P. Moller, T.O. Rognum, et al. 1993. Genomic instability in colorectal cancer: relationship to clincopathological variables and family history. Cancer Res. 53:5849-5852.

4. Jen, J., S.M. Powell, N. Papadopoulos, K.J. Smith, S.R. Hamilton, B. Vogelstein, and R.W. Kinzler. 1994. Molecular determinants of dysplasia in colorectal lesions. Cancer Res. 54:5523-5526.

5. Hill, M.J. 1995. Dietary factors: the intestinal milieu. In Cancer of the Colon, Rectum, and Anus. A. M.Cohen, S. J. Winawar, M.A. Friedman, and L. Gunderson, editors. McGraw Hill, Inc. New York. 27-34.

6. Fishel, R., M.K. Lescoe, M.R.S. Rao, N.G. Copeland, N.A. Jenkins, J.
Garber, M. Kane, and R. Kolodner. 1993. The human mutator gene homolog MSH2 and its association with hereditary non-polyposis colon cancer. Cell. 75 : 1027-1038.

7. Leach, F.S., N.C. Nicolaides, N. Papadopoulos, B. Liu, J. Jen, R. Parsons, P. Pelkomaki, P. Sistoner, L.A. Aaltonen, M. Nystrom-Lahti, et al., 1993. Mutations of a mut $\mathrm{S}$ homolog in hereditary non-polyposis colorectal cancer. Cell. 75 : 1215-1225.

8. Gupta, I., J. Baptista, W.R. Bruce, C.T. Che, R. Furrer, J.S. Gingerich, A.A. Grey, L. Marai, P. Yates, and J.J. Krepinsky. 1983. Structures of fecapentaenes, the mutagens of bacterial origin isolated from human feces. Biochemistry. 22:241-245.

9. Sugimura, T. 1985. Carcinogenicity of mutagenic heterocyclic amines formed during the cooking process. Mutat. Res. 150:33-42.

10. Tempero, M. 1986. Bile acids, ornithine decarboxylase, and cell proliferation in colon cancer: a review. Dig. Dis. 4:49-56.

11. Bartram, H.P., W. Scheppach, H. Schmid, A. Hofmann, G. Dusel, F. Richter, A. Richter, and H. Kasper. 1993. Proliferation of human colonic mucosa as an intermediate biomarker of carcinogenesis: effects of butyrate, deoxycholate, calcium, ammonia and pH. Cancer Res. 53:3283-3288.

12. Morizet, J., A. Gonyetta, and G. G. Chabot. 1992. Comparison of mouse and human colon tumors with regard to phase I and phase II drug-metabolizing enzyme systems. Cancer Res. 52:6567-6575.

13. Meister, A. 1983. A selective modification of glutathione metabolism. Science (Wash. DC). 220:472-477.

14. Seidegard, J., R.W. Pero, M.M. Markowitz, G. Roush, D.G. Miller, and E.J. Beattie. 1990. Isoenzymes of glutathione transferase (class $\mu$ ) as a marker for the susceptibility to lung cancer: a follow-up study. Carcinogenesis (Lond.). 11:33-36.

15. Alexandrie, A.K., M.I. Sundberg, J. Seidegard, G. Tornling, and A. Rannug. 1994. Genetic susceptibility to lung cancer with special emphasis on CYP1A1 and GSTM1: a study on host factors in relation to age at onset, gender, and histological cancer types. Carcinogenesis (Lond.). 15:1785-1790.

16. Szarka, C.E, G.R. Pfeiffer, S.T. Hum, L.C. Everly, A.M. Balshem, D.F. Moore, S. Litwin, E.B. Goosenberg, H. Frucht, P.F. Engstrom, and M. Clapper. 1995. Glutathione S-transferase activity and glutathione S-transferase $\mu$ expression in subjects at risk for colorectal cancer. Cancer Res. 55:2789-2793.

17. Trock, B., E. Lanza, and P. Greenwald. 1990. Dietary fiber, vegetables and colon cancer: critical review and metaanalysis of the epidemiologic evidence. J. Natl. Cancer Inst. 82:650-661.

18. National Research Council, Committee on Diet, Nutrition and Cancer. 1982. National Academy Press, Washington, D.C.

19. Wattenberg, L.W. 1983. Inhibition of neoplasia by minor dietary constituents. Cancer Res. 43:2448-2453.

20. Colditz, G.A., L.G. Branch, R.J. Lipnick, W.C. Willett, B. Rosner, B.M. Posner, and C.H. Hennekens. 1985. Increased green and yellow vegetable intake and lowered cancer deaths in an elderly population. Am. J. Clin. Nutr. 41: 32-36.

21. Kensler, T.W., N.E. Davidson, J.D. Groopman, B.D. Roebuck, H.J. Prochaska, and P. Talalay. 1993. Chemoprotection by inducers of electrophile detoxication enzymes. Basic Life Sci. 61:127-136.

22. Zhang, Y., P. Talalay, C.G. Cho, and G.H. Posner. 1992. A major inducer of protective enzymes from broccoli: isolation and elucidation of structure. Proc. Natl. Acad. Sci. USA. 89:2399-2403.

23. Gentilini, M., B. Duflo, D. Richard-Lenoble, G. Brucker, M. Danis, G. Niel, and Y. Meunier. 1980. Assessment of RP35972 (oltipraz) a new antischistosomal drug against Schistosoma hematobium, Schistosoma mansoni, and Schistosoma intercalatum. Acta Trop. 37:271-274.

24. Wattenberg, L.W., and E. Bueding. 1986. Inhibitory effects of 5-(2pyrazinyl)-4-methyl-1,2-dithiole-3-thione (oltipraz) on carcinogenesis induced by benzo(a)pyrene, diethylnitrosamine, and uracil mustard. Carcinogenesis (Lond.). 7:1379-1381.

25. Rao, C.V., K. Tokoma, G. Kelloff, and B.S. Reddy. 1991. Inhibition by dietary oltipraz of experimental intestinal carcinogenesis induced by azoxymethane in male F344 rats. Carcinogenesis (Lond.). 12:1051-1055.

26. Rao, C.V., A. Rivenson, M. Katiwalla, G.J. Kelloff, and B.S. Reddy. Chemopreventive effect of oltipraz during different stages of experimental colon carcinogenesis induced by azoxymethane in male F344 rats. Cancer Res. 53: 2502-2506.

27. Kensler, T.W., P.A. Egner, P.M. Dolan, J.D. Groopman, and B.D. Roebuck. 1987. Mechanism of protection against aflatoxin tumorigenicity of rats fed 5-(2-pyrazinyl)-4-methyl-1,2-dithiole-3-thione (oltipraz) and related 1,1dithiole-3-thiones and 1,2-dithiole-3-ones. Cancer Res. 47:4271-4277.

28. Davidson, N.C., P.A. Egner, and T.W. Kensler. 1990. Transcriptional control of glutathione-S-transferase gene expression by the chemoprotective agent 5-(2-pyrazinyl)-4-methyl-1,2-dithiole-3-thione (oltipraz) in rat liver. Cancer Res. 50:2251-2255.

29. Ansher, S.S., P. Dolan, and E. Bueding. 1986. Biochemical effects of dithiolethiones. Food Chem. Toxicol. 24:405-415.

30. Ansher, S.S., P. Dolan, and E. Bueding. 1983. Chemoprotective effects of two dithiolethiones and of butylhydroxyanisole against carbon tetrachloride and acetaminophen toxicity. Hepatology (NY). 3:932-935.

31. Katz, N., R.S. Rocha, and A. Chaves. 1982. Dose-ranging clinical trial 
with oltipraz in schistosomiasis mansoni. Rev. Inst. Med. Trop. Sao Paolo 24:4048.

32. Benson, A.B., III. 1993. Oltipraz: a laboratory and clinical review. $J$. Cell. Biochem. 17(Suppl.)F:278-291.

33. Habig, W.H., and W.B. Jakoby. 1981. Glutathione-S-transferases: assays for differentiation of glutathione-S-transferases. Methods Enzymol. 7:398-405.

34. Griffith, O.W. 1980. Determination of glutathione and glutathione disulfide using glutathione reductase and 2-vinylpyridine. Anal. Biochem. 106:207212.

35. Ernster, L. 1967. DT-diaphorase. Methods Enzymol. 10:309-317.

36. Miller, S.A., D.O. Dykes, and H.F. Polesky. 1988. A simple salting our procedure for extracting DNA from human nucleated cells. Nucleic Acids Res. 16:1215.

37. Fryer, A.A., L. Zhao, J. Alldersea, W.R. Pearson, and R.C. Strange. 1993. The glutathione S-transferase: polymerase chain reaction studies on the frequency of the GSTM1 0 genotype in patients with pituitary adenomas. Carcinogenesis (Lond.). 14:563-566.

38. Chomczynski, P., and N. Sacchi. 1987. Single-step method of RNA isolation by acid guanidium thiocyanate-phenol-chloroform extraction. Anal. Biochem. 162:156-159.

39. Horikoshi, T., K.D. Danenberg, T.H. W.Stadlbauer, M. Volkenandt, L.C. Shea, K. Aigner, B. Gustavsson, L. Leichman, R. Frosing, M. Ray, et al., 1992. Quantitation of thymidylate synthase, dihydrofolate reductase, and DTdiaphorase gene expression in human tumors using the polymerase chain reaction. Cancer Res. 52:108-116.

40. Yao, K.-S., A.K. Godwin, S.W. Johnson, R.F. Ozols, P.J. O'Dwyer, and T.C. Hamilton. 1995. Evidence for altered regulation of $\gamma$-glutamylcysteiene synthetase gene expression among cisplatin-sensitive and -resistant human ovarian cancer cell lines: changes in transcription factor expression and function. Cancer Res. 55:4367-4374.

41. Jaiswal, A.K., W.O. McBride, M. Adesnik, and D.W. Nebert. 1988. Human dioxin-inducible cytosolic NAD(P)H:menadione oxidoreductase. cDNA sequence and localization of gene to chromosome 16. J. Biol. Chem. 263:1357213578

42. Ng, S.-Y., P. Gunning, R. Eddy, R., P. Ponte, J. Leavitt, T. Shows, and L. Kedes. 1985. Evolution of the functional human $\beta$-actin gene and its multi- pseudogene family: conservation of non-coding regions and chromosomal dispersion of pseudogenes. Mol. Cell Biol. 5:2720-2732.

43. Board, P.G. 1980. Biochemical genetics of glutathione S-transferase in man. Ann. Hum. Genet. 33:36-43.

44. Strange, R.C., G.C. Faulder, B.A. Davis, R. Hume, J.A. Brown, W. Cotton, and D.A. Hopkinson. 1984. The human glutathione S-transferases: studies on the tissue distribution and genetic variation of the GST1, GST2 and GST3 isoenzymes. Ann. Hum. Genet. 48:11-20.

45. Lafuente, A., F. Pujol, P. Carretero, J.P. Villa, and A. Cuchi. 1993. Human glutathione S-transferase $\mu$ (GST $\mu$ ) deficiency as a marker for the susceptibility to bladder and larynx cancer among smokers. Cancer Lett. 68:49-54.

46. Yao, K.-S., A.K. Godwin, R.F. Ozols, T.C. Hamilton, and P.J. O'Dwyer Variable baseline $\gamma$-glutamylcysteiene synthetase messenger RNA expression in peripheral mononuclear cells of cancer patients, and its induction by buthionine sulfoximine treatment. Cancer Res. 53:3662-3666.

47. Clapper, M.L., L.C. Everley, L.A. Strobel, A.J. Townsend, and P.F. Engstrom. 1994. Coordinate induction of glutathione S-transferase $\alpha, \mu$ and $\pi$ expression in murine liver after a single administration of oltipraz. Mol. Pharmacol. 45:469-474.

48. Yao, K.-S., and P.J. O'Dwyer. 1995. Involvement of NF-kB in the induction of NAD(P)H:quinone oxidoreductase (DT-diaphorase) by hypoxia, oltipraz and mitomycin C. Biochem. Pharmacol. 49:275-282.

49. Egner, P.A., T.W. Kensler, T. Prestera, P. Talalay, A.H. Libby, H.H Joyner, and T.J. Curphey. 1994. Regulation of Phase II enzyme induction by oltipraz and other dithiolethiones. Carcinogenesis (Lond.). 15:177-181.

50. O'Dwyer, P.J., K.-S. Yao, P. Ford, A.K. Godwin, and M. Clayton. 1994. Effects of hypoxia upon detoxicating enzyme activity and expression in HT29 colon adenocarcinoma cells. Cancer Res. 54:3082-3087.

51. Peters, W.H.M., L. Kock, F.M. Nagengast, and H.M.J. Roelofs. 1990. Immunodetection with a monoclonal antibody of glutathione S-transferase mu in patients with and without carcinomas. Biochem. Pharmacol. 39:591-597.

52. Strange, R.C., B. Matharoo, G.C. Faulder, P. Jones, W. Cotton, J.B. Elder, and M. Deakin. 1991. The human glutathione S-transferases: A case-control study of the incidence of the GST10 phenotype in patients with adenocarcinoma. Carcinogenesis (Lond.). 12:25-28. 